\title{
Assessment of hand mobility in patients with rheumatoid arthritis using a computer measurement station
}

\author{
Ocena sprawności ruchowej ręki chorych na reumatoidalne zapalenie stawów \\ $z$ wykorzystaniem komputerowego stanowiska pomiarowego
}

\author{
Mariusz Drużbicki, Jolanta Zwolińska, Grzegorz Przysada, Monika Maj \\ Institute of Physiotherapy, University of Rzeszów \\ Instytut Fizjoterapii Uniwersytetu Rzeszowskiego
}

Key words: rheumatoid hand, hand strength, disability.

Słowa kluczowe: ręka reumatoidalna, siła, niepełnosprawność.

\section{Sum mary}

Background: The study aimed to assess hand mobility (hand strength and grip capacity) in patients with rheumatoid arthritis, by means of objective measurement methods, as well as to evaluate the link between hand fitness and the level of disability in these subjects. Additionally, the authors assessed the impact of disease activity, the duration of morning stiffness and the intensity of pain on the functional condition of the hand.

Material and methods: The study group consisted of 56 patients diag nosed with rheumatoid arthritis. The investigated characteristics included: disease activity measured with DAS28 (Disease Activity Score), disability level measured with HAQ (Health Assessment Questionnaire), as well as intensity of pain and duration of morning stiffness. Hand strength and grip capacity were assessed by means of a specially designed measuring station.

Results: The controls demonstrated significantly greater grip capacity and grip strength in the right hand in comparison with the study group $(p=0.000)$. Additionally, the intensity of pain was found to have a statistically significant impact on the fitness of the examined hand $(r=-57 ; p=0.001)$. Disease activity measured with DAS28 and hand fitness did not correlate significantly $(r=-0.11)$. However, a relationship was demonstrated for the level of functional disability $(\mathrm{HAQ})$ and the parameters of hand fitness $(r=-0.44)$.

Conclusions: In the period of acute rheumatoid arthritis symptoms, hand mobility depends mainly on the intensity of pain. The level of fitness is not affected by the subjects' age, the duration of morning stiffness or the level of disease progression. Hand fitness (hand strength and grip capacity) is a determinant of the disability level in patients with rheumatoid arthritis.

\section{Streszczenie}

Wstęp: Celem pracy była ocena sprawności ruchowej ręki (sity chwytu, objętości chwytu) u chorych z reumatoidalnym zapaleniem stawów (RZS) z wykorzystaniem obiektywnych metod pomiaru oraz ocena związku pomiędzy sprawnością ruchową ręki a stopniem niepełnosprawności badanych chorych. Dokonano też oceny wpływu aktywności procesu chorobowego, czasu trwania sztywności porannej i nasilenia dolegliwości bólowych na stan funkcjonalny ręki. Materiał i metody: Badaniami objęto 56 chorych z rozpoznanym RZS leczonych na oddziale reumatologii. Oceniano aktywność procesu chorobowego wg wskaźnika DAS28 (Disease Activity Score), stopień niepetnosprawności wg kwestionariusza HAQ (Health Assessment Questionnaire), nasilenie dolegliwości bólowych wg skali VAS oraz czas trwania sztywności porannej. Siłę ręki, objętość chwytu ręki oceniono za pomocą oryginalnego komputerowego stanowiska pomiarowego. Wyniki: Wykazano istotnie wyższą wartość objętości chwytu i większą siłę chwytu ręki prawej w grupie kontrolnej w porównaniu $z$ grupą badaną $(p=0,000)$. Stwierdzono też, że poziom nasilenia dolegliwości bólowych miał istotny statystycznie wpływ na sprawność ruchową badanej ręki $(r=-57 ; p=0,001)$. Nie wykazano istotnej zależności pomiędzy poziomem aktywności choroby mierzonej wskaźnikiem DAS28 a poziomem sprawności (sity chwytów) badanych rąk $(r=-0,11)$. Stwierdzono natomiast istotną zależność pomiędzy poziomem funkcjonalnej niesprawności badanych chorych ocenianej wg kwestionariusza HAQ a parametrami sprawności rąk $(r=-0,44)$. Wnioski: W okresie zaostrzenia objawów RZS sprawność ruchowa ręki zależy przede wszystkim od nasilenia dolegliwości bólowych. Na poziom tej sprawności nie wpływa wiek badanych, czas trwania sztywności porannej oraz stopień zaawansowania procesu chorobowego. Sprawność ręki (siła i objętość chwytu) istotnie determinuje poziom niepełnosprawności chorych na RZS.

Adress for correspondence:

dr Mariusz Drużbicki, Instytut Fizjoterapii, Uniwersytet Rzeszowski, ul. Warszawska 26 A, 35-205 Rzeszów, tel. +48 1787219 20,

e-mail: ifizjot@univ.rzeszow.pl; mdruzb@univ.rzeszow.pl

Submitted: 31.08 .2012 


\section{Introduction}

Rheumatoid arthritis (RA) is a chronic, systemic inflammatory disease of the connective tissue of unknown aetiology. It is characterised by inflammation of symmetric joints, the presence of extra-articular changes, and systemic complications. The course of the disease is characterised by hypertrophy of the synovial membrane, bone destruction and destruction of joint cartilage as well as joint deformation and impairment of joint function [1, 2]. The radiocarpal, radioulnar, metacarpophalangeal, and interphalangeal joints of the hand are primary sites for the inflammatory process. Changes taking place in joints are accompanied by joint pain and swelling, morning stiffness, fatigue, and weakness [3].

Disfigurement and deformities of the hands are present in $90 \%$ of patients with RA [4]. They appear relatively early and are an important prognostic factor. In approximately $10 \%$ of patients, the disease process begins with inflammation of the wrist and 10 years after the onset of the disease, $60 \%$ of patients are found to have damage to their wrists [5]. Other studies have demonstrated the presence of typical symptoms and deformities involving the joints of the hand and wrist as early as 2 years after diagnosis of RA [6].

Changes taking place in the rheumatoid hand may lead to significant disability. Pain, deformities and a reduction in muscle strength lead to a decrease in the quality of the grip of the hand and difficulties in performing actions requiring manual dexterity, which has a serious impact on the functioning of the patient in everyday life $[3,7]$.

The most common deformities within the hand, ulnar deviation and palmar deviation, metacarpophalangeal joint subluxation as well as radial deviation in the radiocarpal joint, significantly restrict the gripping and functional abilities of the hand [8-13].

The range of movement of the rheumatoid hand is often restricted, even in the early stages of the disease. Severe pain in the hand also accompanies the cylindrical and hammer grips. The optimal grip for the rheumatoid hand is the hook grip [3, 14]. With the progression of the disease, hand function continues to deteriorate, and the most characteristic feature is a decrease of the strength or an absence of the cylindrical grip [3]. Normal gripping strength of the hand enables individuals to perform all basic self-care tasks as well as more complex functions, for example, work-related activities. The progressive development of symptoms of the disease gradually limits, and finally makes many actions impossible to perform. The activity of the disease process, severe pain and joint deformation significantly restrict muscle strength and muscle endurance as well as gripping ability and manual dexterity, which, combined with psychosocial factors such as loneliness or depression, lead to severe disability and handicap [15-17].
The aim of the study was to assess the strength and volume of the cylindrical grip of the hands of patients with RA, using a computer measurement station, and to assess the relationship between the degree of patients' disability and hand function performance. The study also assessed the relationship between hand function performance and the activity of the disease process, the duration of morning stiffness, and the severity of pain.

\section{Material and methods}

The study was conducted with the participation of patients treated in a rheumatological hospital ward. Patients were enrolled in the study if their diagnosis had been made in accordance with ACR (American College of Rheumatology) criteria for rheumatoid arthritis, the duration of their disease exceeded one year, patients were able to walk unassisted, received physiotherapeutic interventions, and gave their consent to participate in the study. Patients were excluded from the study if they had co-existing neurological diseases, if they had sustained trauma, a prior history of fractures of the upper limbs and hands, or had cardiorespiratory failure. A total of 56 female patients were enrolled in the study. The mean age of patients in the study group was 57.1 years (SD 10.7) with an age range of 38 to 77 years. Thirty healthy females were enrolled in the control group; they had no complaints and were physically normal with regard to the upper extremities. The mean age of females in the control group was 55.3 years (SD 6.5) with an age range of 35 to 68 years.

An assessment of the radiological stage of RA disease according to Steinbrocker (I-IV) was performed in all the patients in the study group, based on the number of tender and swollen joints, and ESR and CRP values, in addition to which an evaluation was made of the activity of the disease process using the DAS28 Index (Disease Activity Score). The degree of disability was calculated using the HAQ questionnaire (Health Assessment Questionnaire). Severity of pain was measured using a visual analogue scale (VAS).

The functional performance of the hand was assessed using an original microcomputer measurement station to measure the grip strength, the area of the palmar surface of the hand and the range of movement in the joints of the hand. Measurements were taken of maximal cylindrical grip strength, of precision two- and three-finger grips, and the duration of sustained maximal cylindrical grip strength. The grip strength was defined as a value of pressure created by grasping a measuring cylinder $(\mathrm{kPa})$. The grip volume was also measured, defined as the volume of air displaced from the measuring cylinder during a cylindrical grip. The expressed air caused the displacement of a bubble in a vessel connected to the measuring cylinder. This dis- 
placement, expressed in millimetres, was a measure of the range of movement in the joints of the hand [18].

A statistical analysis of the results of the study was performed using version 9 of the Statistica program. The relationship between the studied parameters was estimated by Spearman's rank correlation coefficient. The level of significance of differences was established using the MannWhitney test. The level of significance was set at $p \leq 0.05$.

\section{Results}

The studied group of patients had a high level of disease activity, indicative of disease exacerbation (DAS > 5.1). The study subjects were characterised by a significant degree of disability (the average level of disability in the study group, measured using the HAQ questionnaire, was 1.39). In addition, the results revealed that patients were experiencing severe pain (average level of pain measured on the VAS scale was $6.28 \mathrm{~cm}$ ). The duration of morning stiffness was, on average, 2.5 hours (Table I).

A comparison was conducted of the results of hand measurements obtained in both groups. No statistically significant differences were found between the two studied groups with regard to the area of the palmar surface of the hand. However, there were significant differences in the volume of the grip of the hand and in the gripping strength of the right hand; the control group had the more favourable results. The study did not reveal any statistically significant differences between groups with regard to duration of sustained maximal grip strength (Table II). In the study group as well as the control group, the results of all the tests conducted on subjects' right and left hands were very similar (the difference between the results for subjects' right and left hands was statistically non-significant).

The study also included an analysis of the relationship between functional mobility (expressed as strength and volume of the grip of the hand) and the patient's age, stage of disease (expressed as the degree of progression of radiological changes), the duration of morning stiffness, and the severity of pain. Among all the studied factors, only the level of severity of pain had a statistically significant effect on the functional performance of the studied hand. Study participants with more severe pain had lower functional performance. Unquestionably stronger correlations were observed in the left hand - here most of the relationships

Table I. Clinical and demographic characteristics of studied patients

\begin{tabular}{|lccccc|}
\hline Studied parameters & $\bar{x}$ & Me & s & Min. & Max. \\
\hline age (in years) & 57.10 & 57.00 & 10.70 & 38.00 & 77.00 \\
\hline DAS28 & 6.15 & 6.11 & 1.21 & 3.32 & 8.40 \\
\hline HAQ & 1.39 & 1.45 & 0.60 & 0.15 & 2.25 \\
\hline $\begin{array}{l}\text { pain severity according } \\
\text { to VAS (cm) }\end{array}$ & 6.28 & 6.50 & 1.76 & 2.60 & 10.00 \\
\hline $\begin{array}{l}\text { duration of morning } \\
\text { stiffness (h) }\end{array}$ & 2.50 & 2.00 & 2.30 & 0.50 & 12.00 \\
\hline
\end{tabular}

Table II. Numerical characteristics for the parameters of hand mobility in the study group and controls

\begin{tabular}{|c|c|c|c|c|c|c|c|}
\hline \multirow{3}{*}{$\begin{array}{l}\text { Functional parameters } \\
\text { (right hand) }\end{array}$} & \multicolumn{6}{|c|}{ Group } & \multirow[t]{3}{*}{$p$} \\
\hline & \multicolumn{3}{|c|}{ study group } & \multicolumn{3}{|c|}{ control group } & \\
\hline & $\bar{x}$ & $\mathrm{Me}$ & $s$ & $\bar{x}$ & $\mathrm{Me}$ & $s$ & \\
\hline area of the hand $\left(\mathrm{mm}^{2}\right)$ & 12575.0 & 12379.0 & 2445.0 & 13111.0 & 13527.0 & 1674.0 & 0.1751 \\
\hline grip volume $\left(\mathrm{mm}^{3}\right)$ & 14.5 & 14.3 & 3.4 & 21.9 & 22.7 & 3.7 & $0.0000^{* * *}$ \\
\hline cylindrical grip strength (kPa) & 16.4 & 14.6 & 10.7 & 49.7 & 52.5 & 19.4 & $0.0000^{* * *}$ \\
\hline precision grip strength I-III & 11.3 & 10.0 & 6.2 & 27.0 & 23.9 & 12.6 & $0.0000^{* * *}$ \\
\hline precision grip strength I-II & 8.5 & 7.7 & 4.4 & 18.5 & 16.7 & 7.6 & $0.0000^{* * *}$ \\
\hline $\begin{array}{l}\text { duration of sustained maximal } \\
\text { strength (s) }\end{array}$ & 2.6 & 2.2 & 1.7 & 3.0 & 3.0 & 1.3 & 0.2492 \\
\hline
\end{tabular}


Table III. Correlations between measurements of hand mobility and subjects' age, duration of the disease, duration of morning stiffness, and pain intensity

\begin{tabular}{|c|c|c|c|c|}
\hline Functional parameters & Age & $\begin{array}{l}\text { Disease } \\
\text { duration }\end{array}$ & $\begin{array}{l}\text { Duration of morning } \\
\text { stiffness (h) }\end{array}$ & VAS \\
\hline grip volume $\left(\mathrm{mm}^{3}\right)$ right hand & 0.16 & -0.08 & -0.07 & $-0.44^{\star}$ \\
\hline grip volume $\left(\mathrm{mm}^{3}\right)$ left hand & 0.21 & 0.05 & 0.03 & $-0.50^{\star \star}$ \\
\hline cylindrical grip strength $(\mathrm{kPa})$ right hand & 0.02 & 0.00 & 0.12 & -0.37 \\
\hline cylindrical grip strength $(\mathrm{kPa})$ left hand & 0.05 & -0.09 & -0.03 & $-0.59^{\star *}$ \\
\hline precision grip strength I-III right hand & 0.07 & -0.04 & 0.13 & -0.27 \\
\hline precision grip strength I-III left hand & -0.02 & -0.05 & 0.07 & $-0.58^{* *}$ \\
\hline precision grip strength I-II right hand & 0.00 & -0.01 & 0.11 & -0.33 \\
\hline precision grip strength |-II left hand & -0.13 & -0.03 & 0.09 & $-0.60^{* * *}$ \\
\hline $\begin{array}{l}\text { duration of sustained maximal strength (s) } \\
\text { right hand }\end{array}$ & 0.20 & -0.21 & -0.13 & -0.13 \\
\hline $\begin{array}{l}\text { duration of sustained maximal strength (s) } \\
\text { left hand }\end{array}$ & 0.02 & -0.28 & -0.06 & -0.26 \\
\hline
\end{tabular}

could be described as average (Spearman's coefficient, 0.5 $\leq|R|<0.7)$ (Table III).

An analogous method was applied to study the relationship between the level of disease activity and the functional ability of studied hands (Table IV). With regard to the right hand, the results showed no statistically significant relationship between the level of disease activity, as measured by DAS28, and the functional mobility of the hand expressed as volume of the grip of the hand, the strength of the respective grips of the hand and the duration of sustained maximal grip strength. For the left hand, correlations between its functional mobility and the level of disease activity were slightly higher, but no statisti- cally significant relationship was established. The correlation between DAS28 and cylindrical grip strength in the left hand $(R=-0.36)$ had borderline statistical significance ( $p=0.0569)$.

Furthermore, an analysis was conducted of the relationship between the level of functional disability (HAQ) and the results of functional mobility measurements (Table IV). Most of the examined relationships were statistically significant; the strength of the respective relationships may be described as average. Negative values of correlation coefficients indicate that with increasingly higher (improved) results of functional mobility measurements, the level of disability decreases (HAQ scores continue to fall).

Table IV. Correlations between measurements of hand function and values of DAS28 and HAQ scores

\begin{tabular}{|lcccc|}
\hline Functional parameters & \multicolumn{2}{c}{ DAS28 } & \multicolumn{2}{c|}{ HAQ } \\
\cline { 2 - 5 } & right hand & left hand & left hand \\
\hline $\begin{array}{l}\text { grip volume }\left(\mathrm{mm}^{3}\right) \\
\text { cylindrical grip }\end{array}$ & -0.02 & 0.04 & $-0.49^{\star *}$ & $-0.43^{\star}$ \\
\hline $\begin{array}{l}\text { strength (kPa) } \\
\text { precision grip }\end{array}$ & -0.11 & -0.36 & $-0.44^{*}$ & $-0.56^{* *}$ \\
\hline $\begin{array}{l}\text { strength I-III } \\
\text { precision grip }\end{array}$ & -0.11 & -0.15 & $-0.47^{\star}$ & $-0.56^{* *}$ \\
\hline strength I-II & -0.11 & -0.22 & $-0.51^{* *}$ & $-0.53^{* *}$ \\
\hline $\begin{array}{l}\text { duration of sustained } \\
\text { maximal strength (s) }\end{array}$ & -0.30 & 0.05 & $-0.40^{*}$ & -0.24 \\
\hline
\end{tabular}




\section{Discussion}

The activity and functional ability of patients with RA depends to a significant extent on the progression of the disease process [19]. The most common abnormalities and dysfunctions are those associated with disturbed hand function [20]. These disorders have a particularly strong effect on patients' quality of life. Disturbed grip function can often appear as early as the initial stages of the disease, making it difficult to perform everyday functions, and it is one of the main causes of disability in patients [3, 21].

The study was conducted in a group of patients treated on a rheumatological ward for exacerbation of their disease. The mean DAS28 score in the study group was 6.15. In a study assessing the strength of the flexor muscles of the hand in a group of patients with RA and a control group, Woźniewski et al. [22] demonstrated that the hand strength of patients with RA is $40 \%$ lower compared to the strength of healthy subjects' hands. The results of an original study indicated that the difference in muscle strength was significantly larger. During disease exacerbations, muscle strength measured in the cylindrical grip and precision two- and three-finger grips was significantly lower compared with the results of muscle strength measurements in the control group. The difference, compared with the control group, was almost three-fold. The volume of the cylindrical grip (volume of air displaced from the cylinder) was also significantly smaller in the study group. It must be added that there were no significant differences in the area of the palmar surface of the hand between the two groups. Measuring the grip volume is an indirect method of evaluating mobility in the joints of the fingers of the hands and the result of the study confirmed significant limitation of the range of motion and the unquestionably limiting effect of pain on movement.

An assessment was also made of strength endurance expressed as the duration of sustained maximal and submaximal strength of cylindrical grip. Subjects in the study group were able to maintain maximal grip strength over a mean period of $2.6 \mathrm{~s}$ while subjects from the control group maintained maximal grip strength for $3 \mathrm{~s}$. The difference was not statistically significant. We may therefore assume that in patients with RA, the strength endurance needed in everyday life in order to perform many self-care tasks is probably maintained at a level similar to healthy individuals and the main limitation on muscle function is the result of significantly lower strength.

According to Żuk and Księżopolska-Orłowska [3], the gripping strength of a hand affected by rheumatoid arthritis depends on the stage of the disease. In the study group, there was no statistically significant relationship between the strength of the grip of the hand and the degree of radiological progression, which may be a result of the presence of disease exacerbation and severe pain, the most significant factors affecting the degree of functional ability of the hands of studied patients. Furthermore, there was no significant correlation between the duration of morning stiffness and the level of hand function performance.

The restriction of the range of movement of the joints and reduction in muscle strength restrict functional capacity and are the cause of progressive disability [21]. Wisłowska et al. [23] demonstrated a statistically significant correlation between quality of life assessed using the SF-36 survey and patients' age, disease duration, ESR value, CRP concentration, and the severity of pain. The statistically significant relationship between the severity of pain demonstrated in the study, measured on the VAS scale, and the parameters of functional mobility of the hand confirm the findings of studies by Rupiński and Filipowicz-Sosnowska [24]. The authors demonstrated that evaluation of the severity of pain may be an easy-to-use test that can determine the approximate degree of risk of developing disability in patients with RA over the age of 55 years.

The HAQ questionnaire is one of the more important indicators of disability and enables assessment of the overall fitness of an individual in the performance of everyday activities. It is assumed that a value of $\mathrm{HAQ}>1$ is a clinical exponent of disability and signifies a degree of restriction on most aspects of everyday life [24]. Factors that have a significant effect on the degree of disability are disease activity, structural changes within the locomotor system, and psychosocial factors [16]. Factors directly associated with the disease (activity of the inflammatory process, joint destruction, and pain) are responsible for $50-70 \%$ of variability in the HAQ score [24]. According to Olewicz-Gawlik and Hrycaj [25], determination of the DAS score and the $\mathrm{HAQ}$ coefficient make it possible to predict, with a high degree of accuracy, the course of the disease, progression of radiological changes, and disability.

Studies investigating levels of functional ability in patients with RA have shown that limitations in the ability to perform basic daily activities were associated with joint pain, the presence of morning stiffness, and low hand muscle strength [26]. Dias et al. [27] also demonstrated a significant correlation between the range of movement in the joints of the hand (the so-called functional range of movement of the hand was assessed) and a subjective assessment by the patient expressed in the form of a disability scale. Meanwhile, Nordenskiöld and Grimby [15] demonstrated a relationship between the degree of functional ability to perform everyday activities and hand muscle strength. The authors established that the majority of patients with RA (65\%) avoid performing tasks that require a significant amount of strength and manual dexterity as well as functions that require simultaneous involvement of a large number of joints. 
In our original studies, the computer-assisted method of measuring the strength of the cylindrical grip and the two- and three-finger grips enabled objective and precise functional assessment of the hand itself. These measuring methods, used to evaluate the state of health of patients with RA, enable appropriate planning and necessary modification, if required, of therapeutic rehabilitation programmes for these patients. The value of the results obtained in studies may, however, be slightly limited since, according to Rupp et al. [25], studies investigating the effect of variables associated with RA activity on quality of life and disability should be designed with a patient followup period of several years. Thus, there is a valid need to conduct long-term studies with the participation of larger groups, assessing the correlation between the degree of hand dysfunction and the level of disability and level of disease activity in patients with RA.

\section{Conclusions}

1. During periods of exacerbation of symptoms of the disease, hand function performance in female subjects depended primarily on the severity of pain. Patients' age, duration of morning stiffness and the stage of the disease did not affect the level of hand function performance.

2. Functional mobility determines the degree of disability of patients with RA.

3. It is necessary to conduct further studies on a larger group of patients in order to assess changes in hand dysfunction and define the factors that influence these changes in the course of RA.

The authors declare no conflict of interest and no funding.

\section{References}

1. Jaworek J, Jasiak-Tyrkalska B, Matejak M, Jaworek A. Próba oceny wpływu leczenia infliximabem na sprawność ruchową chorych z reumatoidalnym zapaleniem stawów. Badania wstępne. Rehabilitacja Medyczna 2005; 9: 7-13.

2. Olek-Hrab K, Samborski W, Atarowska M, Żaba R. Wspótistnienie pustulosis palmo-plantaris i reumatoidalnego zapalenia stawów u 64-letniej chorej. Post Dermatol Alergol 2003; 20: 41-45.

3. Żuk B, Księżopolska-Orłowska K. Ochrona stawów w reumatoidalnym zapaleniu stawów. Czynności dnia codziennego. Reumatologia 2009; 47: 193-201.

4. Jung L, Śmiłowicz M. Podstawowe zasady leczenia ręki reumatoidalnej. Ortopedia, Traumatologia, Rehabilitacja 2000; 4: 48-50.

5. Jung L, Michalak C, Stowińska I. Leczenie operacyjne nadgarstka reumatoidalnego. Reumatologia 2006; 44: 102-105.

6. Horsten NC, Ursum J, Roorda LD, et al. Prevalence of hand symptoms, impairments and activity limitations in rheumatoid arthritis in relation to disease duration. J Rehab Med 2010; 42: 916921.

7. Johnsson PM, Eberhardt K. Hand deformities are important signs of disease severity in patients with early rheumatoid arthritis. Rheumatology 2009; 48: 1398-1401.
8. Frankowska M, Frankowski S, Nowak D i wsp. Studium anatomii i patomechaniki stawów śródręczno-paliczkowych ręki prawidłowej i u chorych z reumatoidalnym zapaleniem stawów. Kwart Ortop 2000; 1: 5-11.

9. Mazurek T, Lorczyński A. Operacyjne leczenie zerwań ścięgien prostowników palców ręki w przebiegu reumatoidalnego zapalenia stawów. Ann Acad Med Gedan 2003; 33: 129-131.

10. Lesiak A. Rehabilitacja osób z chorobami reumatycznymi. W: Rehabilitacja Medyczna, Kwolek A (red.). Wydawnictwo Medyczne Urban \& Partner, Wroctaw 2003.

11. Zakrzewska M, Sibiński M, Kozłowski P i wsp. Deformacje ręki w przebiegu reumatoidalnego zapalenia stawów u dorosłych i młodzieńczego idiopatycznego zapalenia stawów. Chirurgia Narządu Ruchu 2009; 74: 283-288.

12. Zimmermann-Górska I. Choroby reumatyczne. Wydawnictwo Lekarskie PZWL, Warszawa 2004; 143-163.

13. Mackiewicz S, Hrycaj P. Reumatoidalne zapalenie stawów. W: Reumatologia. Mackiewicz S, Zimmermann-Górska I (red.). Wydawnictwo Lekarskie PZWL, Warszawa 1995; 87-101.

14. Boscheinen-Morrin J, Conolly WB. The hand: Fundamentals of Therapy. Third Edition, Butter-worth Heinemann 2001.

15. Nordenskiöld U, Grimby G. Assesment of disability in women with rheumatoid arthritis. In relation to grip force and pain. Disabil Rehabil 1997; 19: 13-19.

16. Filipowicz-Sosnowska A, Rupiński R. Złożoność procesu niepełnosprawności $u$ chorych na reumatoidalne zapalenie stawów. Reumatologia 2005; 43: 138-146.

17. Scott DL, Garrood T. Quality of life measures: use and abuse. Baillieres Best Pract Res Clin Rheumatol 2000; 14: 663-687.

18. Zwolińska J, Kwolek A, Bieniasz W i wsp. Przydatność niektórych metod służących do diagnostyki i oceny efektów rehabilitacji pacjentów z zespołami neurologicznymi. Przegląd Medyczny Uniwersytetu Rzeszowskiego 2009; 2: 154-161.

19. Meireles SM, Jones A, Jennings F, et al. Assessment of the effectiveness of low-level laser therapy on the hands of patients with rheumatoid arthritis: a randomized double-blind controlled trial. Clin Rheumatol 2010; 29: 501-509.

20. Bączyk G. Przegląd badań nad jakością życia chorych na reumatoidalne zapalenie stawów. Reumatologia 2008; 46: 372-379.

21. Escalante A, Del Rincón I. The disablement process in rheumatoid arthritis. Arthritis Rheum 2002; 47: 333-342.

22. Woźniewski M, Skrzek A, Sabir H i wsp. Czynność ręki i stawu kolanowego po krioterapii ogólnoustrojowej i ćwiczeniach u chorych na reumatoidalne zapalenie stawów. Reumatologia 2001; 39: 155-163.

23. Wisłowska M, Kanecki K, Tyszko P i wsp. Jakość życia zależna od zdrowia u pacjentów z reumatoidalnym zapaleniem stawów. Reumatologia 2010; 48: 104-111.

24. Rupiński R, Filipowicz-Sosnowska A. Aktywność choroby a niepełnosprawność u chorych na reumatoidalne zapalenie stawów. Reumatologia 2005; 43: 129-137.

25. Olewicz-Gawlik A, Hrycaj P. Jakość życia chorych na reumatoidalne zapalenie stawów - badania własne i przegląd literatury. Reumatologia 2007; 45: 346-349.

26. Bączyk G, Gacek L. Ocena sprawności funkcjonalnej chorych na reumatoidalne zapalenie stawów na podstawie funkcjonalnego testu z wystandaryzowanym wyposażeniem. Reumatologia 2011; 49: 40-46.

27. Dias JJ, Smith M, Singh HP, Ullah AS. The working space of the hand in rheumatoid arthritis: its impact on disability. J Hand Surg Eur 2009; 34: 465-470. 